\title{
Antibacterial Activity From Cucumber (Cucumis sativus .L) Ethanol Extract In Deodorant Roll On Dosage Form
}

\author{
Laila Susanti*, Subur Widodo, Qurrota Aini, Dyah Rahmawati \\ Pharmacy Department, University Of Tulang Bawang Lampung
}

\begin{abstract}
Abstrak
Bau badan manusia biasanya terjadi akibat adanya produksi berlebih dari kelenjar keringat dan adanya bakteri. Bahan aktif untuk mencegah bau badan adalah bahan kimia dari tawas atau natrium, tetapi memiliki efek negatif seperti iritasi kulit, penyakit Alzheimer, kanker prostat dan kanker payudara. Teknologi bahan alami untuk mengatasi bau badan telah dikembangkan sebagai bahan aktif dengan menggunakan ketimun (Cucumis sativus .L). Tujuan dari penelitian ini adalah untuk menghasilkan deodoran yang stabil dan berkualitas secara fisik dan juga mengembangkan penggunaan ekstrak ketimun sebagai antibakteri Staphylococcus epidermidis. Ekstraksi ketimun telah dilakukan dengan maserasi menggunakan etanol $70 \%$ selama 4 hari dan kemudian dibagi menjadi tiga formulasi ekstrak $(5 \%, 10 \%$, dan $20 \%$ (b / v)). Semua formulasi telah diuji zona penghambatan, organoleptik, homogenitas, $\mathrm{pH}$, viskositas dan uji iritasi. Hasilnya, semua formulasi memenuhi persyaratan mutu fisik formulasi ekstrak dengan formulasi terbaik adalah kandungan ekstrak 20\% yang mampu menghambat bakteri dengan zona hambat terbesar yaitu $26 \mathrm{~mm}$. Selain itu, stabilitas dipercepat deodoran diuji selama 35 hari pada suhu kamar $\left(28^{\circ} \mathrm{C}\right)$ dan $40^{\circ} \mathrm{C}$. Hasil pengujian menunjukkan bahwa kestabilan ekstrak $10 \%$ memenuhi syarat kualitas fisik selama penyimpanan pada suhu kamar $\left(28^{\circ} \mathrm{C}\right)$ dan suhu tinggi $\left(40^{\circ} \mathrm{C}\right)$ selama 35 hari. Sedangkan pada ekstrak $20 \%$, pada suhu tinggi $\left(40^{\circ} \mathrm{C}\right)$ terjadi perubahan fisik yang ditandai dengan pengendapan.
\end{abstract}

Kata kunci: ketimun, deodoran, antibakteri

\begin{abstract}
Body odor of human skin usually occur due to excessive production of sweat glands couples with the presence of bacteria. The active ingredient to prevent body odor are chemicals materials from alum or sodium in order to have negative effects such as skin irritation, Alzheimer disease, prostate and breast cancer. Natural materials technology has been development as an active agent by using cucumber (Cucumis sativus .L). The purpose of this research to conduct a deodorant roll on a stable and qualified physical quality and also develop the use of extract cucumber as an antibacterial Staphylococcus epidermidis. Cucumber extraction has been done by maceration with ethanol $70 \%$ for 4 days and then divided into three formulation extract $(5 \%, 10 \%$, and $20 \%(\mathrm{~b} / \mathrm{v}))$. All of the formulations has been tested by zone inhibition, organoleptic, homogenity, $\mathrm{pH}$, viscosity and irritation test. The results given that all of the formulations meet the quality requirements of physical and the best formulation extract $20 \%$ able to inhibit bacterial by $26 \mathrm{~mm}$ as a largest diameter of the inhibitory zone. In addition the stability of deodorant roll on form were performed accelerated stability test for 35 days at room temperature $\left(28^{\circ} \mathrm{C}\right)$ and $40^{\circ} \mathrm{C}$. The test results indicate that the stability of the extract $10 \%$ qualified physical quality during storage at room temperature $\left(28^{\circ} \mathrm{C}\right)$ and high temperature $\left(40^{\circ} \mathrm{C}\right)$ for 35 days. While in the extract $20 \%$ at high temperature $\left(40^{\circ} \mathrm{C}\right)$ physical changes characterized by the deposition.
\end{abstract}

Keyword : cucumber, deodorant roll on, antibacteria 


\section{Introduction}

Sweat glands in the human eccrine and apocrine glands are always carrying out its functions the body to sweat when the heat began to whack. Parts of the body that have these glands are the armpit, back of the neck, legs, and other body folds. Excessive sweating will cause the surface of the skin and hair that grows around the area becomes moist, the course will grow bacteria. The excessive amount of sweat that will be broken down by bacteria into acidic compounds that cause body odor. Factors that affect not only the body odor of bacterial activity, but could be due to genetic factors, emotional state, dietary factors, and diseases [1]. Nevertheless, the sweat and the activity of bacteria is believed to have an important role causing body odor. Some bacteria are often present that cause body odor is Corynebacteria sp, Streptococcus sp, Staphylococcus sp and Propionibacteria $s p$ [2].Various ways can be done to reduce the body odor by preventing the activity of bacteria, one with a cosmetic preparation in the form of deodorant.

Deodorant preparations usually liquid, aerosol, ointment, gel, powder and sticks but the most common form of aerosol and liquid [3]. In general, the active ingredient in deodorant is a chemical compound derived from alum, chlorine and sodium. Although these chemical compounds believed to inhibit bacterial activity, but the use of a chemical compound applied to the skin for long periods can cause some side effects that irritate the skin, the symptoms of Alzheimer's, prostate cancer and breast cancer. In 2005, Darbre et al., published works indicating a link between the use of underarm cosmetics such as aluminium-based antiperspirants and breast cancer. Results reported here demonstrate that aluminium in the form of aluminium chloride or aluminium chlorhydrate can interfere with the function of oestrogen receptors of MCF7 human breast cancer cells both in terms of ligand binding and in terms of oestrogen-regulated reporter gene expression.

On the basis of this background, the researchers are encouraged to make deodorant cosmetic preparation using herbal-based active substances. The use of herbal ingredients because Indonesia is a country rich in medicinal plants and has a high efficacy and low side effects. One of the plants is efficacious as an antibacterial that can be used as an active ingredient in the preparation of deodorant is cucumber. Cucumber contains saponin which is antibacterial, antiinflammatory, anti tumor [4].

Saponin is a surface-active compounds that are like soap and has antimicrobialpower. Saponins same function as flavonoids and phenolic compounds that have the ability to inhibit the action of the enzyme, because the compound inhibits the action of an enzyme that causes the enzyme permease can not function properly, so that the transport process can not take place. This resulted in the transport of nutrients does not take place, so that bacterial cells can not grow [5].

Some researchers have reported the active substance saponin as an antibacterial, the peels and pulp of cucumber in phospate buffer saline extracts demonstrated antibacterial activity specifically against gram positive Staphylococcus aureus and gram negative Klebsiella pneumonia ( $\mathrm{Ni}$ Foong et al., 2015). The chloroform fraction of the crude methanol extract of cucumber (Cucumis sativus L.) stems are detected as (2S,3S,4R, 10E)-2-[(2'R)-2-hydroxytetracosanoylamino]-1,3,4-octadecanetriol-10ene,1-O-b-D-glucopyranosyl(2S,3S,4R,10E)2-[(2'R)-2-hydroxy-tetracosanoylamino]1,3,octadecanetriol-10-ene and soya-cerebrosidposses antimicrobial activity [6].

In this study, the researchers made preparations in the form of roll on deodorant with cucumber extract as active substances against on bacteria Staphyloccocus epidermidis. The background of this 
preparation election to the ease and efficiency during use. Excellence deodorant roll on contains a large amount of alcohol (ethanol 96\%) that give the sensation of cold that cooling the skin, and also to keep the clothes stay dry after application preparation without the need to wait too long because the ethanol contained in the preparation will soon evaporate at room temperature.

The optimum formulation results from the manufacture of deodorant roll on to test the homogeneity, organoleptic test, measuring $\mathrm{pH}$, viscosity, density, irritation test, hedonic test, stability test and test of inhibition against the bacteria Staphylococcus epidermidis and accelerated stability test for 35 days at a storage temperature $28^{\circ} \mathrm{C}$ and $40^{\circ} \mathrm{C}$.

\section{Materials and Methods}

Materials

Materials used are bacteria Staphylococcus epidermidis, Mueller Hinton agar medium, distilled water, sodium metabisulfite, aluminum foil, paper towels, propylene glycol, HPCM, oleum rosae. The tools used are incubators, stirrer, scales, $\mathrm{pH}$ meters digital, glass tools, pycnometer, sterile petri dish, viscometer Hooke, paper disc, forceps, rotary evaporator, ose needle sterile autoclave, oven, sterile cotton, plastic bottles, deodorant roll on bottle, boron silica spheres. Determination of plants was conducted in Labotatorium Botany Department of Biology, University of Lampung.

Table 1. The Evaluation Organoleptic of Deodorant Roll On

\begin{tabular}{ccc}
\hline \multirow{2}{*}{ Formulation } & \multicolumn{2}{c}{ Organoleptic } \\
\cline { 2 - 3 } Blanko & Color & Smell \\
1 & Clear Yellow & Rosae \\
2 & Light Yellow & Rosae \\
3 & Yellow & Rosae \\
\hline
\end{tabular}

Preparation of Simplisia

Cucumbers were randomly selected from the local farm in Lampung with the characteristics of green fruit skin and white flesh. They were throughly washed and scrubbed, then left to dried in the sun with black layer.

Preparation of Cucumber Extract

Cucumber extract were made in the following manner : 262 grams of simplisia were weighed and then macerated for 4 days with $70 \%$ ethanol while stirring often squeezed then filtered and washed with $70 \%$ ethanol, and so on until the active ingredients in botanicals maximum filtered. Then, extract carried evaporation using a rotary evaporator until all the ethanol separately.

Preparations Deodorant Roll On From Cucumber Extract

Formulations. Deodorant roll on formulations made with cucumber extract three concentration of the 5, 10 and $20 \%$ $\mathrm{w} / \mathrm{v}$ as formulation 1 , formulation 2 and formulation 3, respectively. In previous study, Yusvaneli (2008) has been test bacterial inhibition cucumber extract against Staphylococcus epidermidis at concentrations of 5\%. [7].

Each concentration cucumber extract supplemented with hidroxypropil celullose medium (HPCM) 2\% w/v, propylene glycol $15 \% \mathrm{w} / \mathrm{v}$, sodium bisulfite $0.1 \% \mathrm{w} / \mathrm{v}$, perfume and o oleum rosae 5 drops of distilled water to $100 \mathrm{~mL}$. The same treatment is given to formula blank.

Table 2. The Evaluation $\mathrm{pH}$ of Deodorant Roll On

\begin{tabular}{cc}
\hline Formulation & $\mathbf{p H}$ \\
\hline Blanko & 5,49 \\
1 & 5,50 \\
2 & 5,50 \\
3 & 5,59 \\
\hline
\end{tabular}


Table 3. The Evaluation Viscosities of Deodorant Roll On

\begin{tabular}{cc}
\hline Formulation & $\begin{array}{c}\text { Viscosities } \\
\text { (cps) }\end{array}$ \\
\hline Blanko & 180,009 \\
1 & 80,211 \\
2 & 171,642 \\
3 & 187,123 \\
\hline
\end{tabular}

Stirring speed optimization. HPCM developed with some of the water is then mixed with cucumber extract and additional materials then homogenized with a stirrer on a stirring speed of 100 , 200, $300 \mathrm{rpm}$ with a stirring for 20 minutes and then allowed to stand. Deodorant roll on formulations homogeneous indicates optimum speeds.

Stirring time optimization. The optimum stirring speed that has been obtained is used to find the optimum stirring time. With the same composition, the sample was stirred at optimum speed at in the stirring time 10, 20 and 30 minutes, and then sample allowed to stand. The optimum stirring time is the time that can be obtained from the sample in a homogeneous state.

Procedure. Deodorant roll on samples made using a formula that has been determined the optimum time and optimum speed with the following steps : weighed materials be required, developed HPCM insome of the water and let stand for 24 hours and then added propylene glycol to the HPCM which has been developed in some of the water and mix until homogeneous. Sodium metabisulfite dissolved in some
Table 4. The Evaluation Iritation Test of Deodorant Roll On

\begin{tabular}{ccccccccccc}
\hline \multirow{2}{*}{$\begin{array}{c}\text { Formu } \\
\text { lation }\end{array}$} & \multicolumn{7}{c}{ Score } \\
\cline { 2 - 8 } & \multicolumn{7}{c}{ Female } & \multicolumn{7}{c}{ Male } \\
\hline Blanko & - & - & - & - & - & - & - & - & - & - \\
1 & - & - & - & - & - & - & - & - & - & - \\
2 & - & - & - & - & - & - & - & - & - & - \\
3 & - & - & - & - & - & - & - & - & - & - \\
\hline
\end{tabular}

of the water, then mix with extracts cucumber with the amount of 5, 10, and 20 grams as formulation 1, formulation 2 and formulation 3 , respectively. Then added oleum rosae 5 drops, stir homogeneous then added with distilled water until $100 \mathrm{ml}$. Then put it into container of bottles with a ball inserted into the neck of the bottle ( \pm $1 \mathrm{~cm}$ from the top surface of the bottle) to discharge.

Accelerated Stability Test

Deodorant roll on samples that have been made at the optimum condition to do accelerated stability testing include organoleptic evaluation, homogeneity, $\mathrm{pH}$, viscosity and flow properties. The sample were kept at different storage temperature i.e. $\pm 28-30^{\circ} \mathrm{C}$ and $40^{\circ} \mathrm{C}$ in the oven with stability chambers and observed for 35 days. Both of the storage temperature, the sample was observed for 5 weeks and then to do the physical evaluation every 1 week. [8].

\section{Results and Discussion}

Results of determination cucumber

Table 5. The Evaluation Hedonic Test of Deodorant Roll On

\begin{tabular}{ccccccccccccc}
\hline \multirow{1}{*}{ Formulation } & \multicolumn{1}{c}{ Score } & \multicolumn{1}{c}{ Male } & Average \\
\cline { 2 - 12 } & 3 & \multicolumn{1}{c}{ Female } & \multicolumn{1}{c}{ Total } & \\
\hline Blanko & 3 & 2 & 1 & 1 & 2 & 3 & 2 & 2 & 2 & 1 & 19 & 1,9 \\
1 & 2 & 2 & 1 & 2 & 2 & 2 & 2 & 2 & 2 & 2 & 19 & 1,9 \\
2 & 4 & 2 & 3 & 3 & 2 & 5 & 4 & 4 & 4 & 3 & 30 & 3,0 \\
3 & 5 & 3 & 4 & 4 & 3 & 5 & 3 & 3 & 3 & 3 & 36 & 3,6 \\
\hline
\end{tabular}




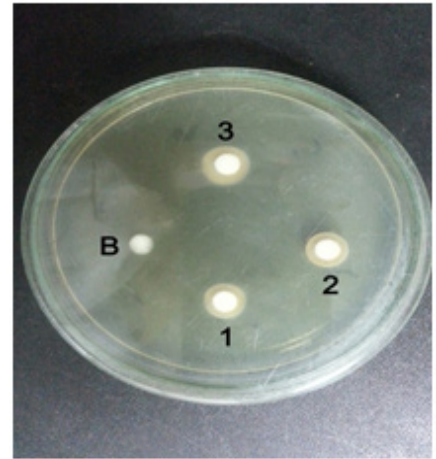

Figure 1. Test Results of Inhibition by Paper Disc

plants were conducted at the Laboratory Botany Department of Biology, University of Lampung. Determination cucumber plants showed that the plants belonging to the species Cucumis sativus L.

Based on the results of the optimization stirring speed sample showed that the homogeneity of sample at a speed of 300 $\mathrm{rpm}$, and the optimization results in 20 minutes stirring time indicates the sample has been homogenized during 24 hours. These results indicate that the higher rotational speed per minute, and the longer time given during the mixing process provides homogeneous sample with a good level.

The results of organoleptic examination visually indicates that the negative control, formulations 1, 2, and 3 deodorant roll on show variations in color are shown in Table
Table 6. Evaluation of Inhibition Test

\begin{tabular}{cc}
\hline Formulation & $\begin{array}{c}\text { Zone Inhibition } \\
\text { diameter (mm) }\end{array}$ \\
\hline Blanko & - \\
1 & 16 \\
2 & 18 \\
3 & 26 \\
\hline
\end{tabular}

1. The color ranging from clear, light yellow to yellow due to different concentrations of extracts of cucumber and produces the smell of roses for use oleum rosae as a perfume in the preparation.

The evaluation of $\mathrm{pH}$ indicate that formulation negative control, 1, 2, and 3 is not significantly different. This results indicates that the higher concentration of cucumber fruit extract used, the $\mathrm{pH}$ will increase. The evaluation of $\mathrm{pH}$ are shown in Table 2.

Evaluation of deodorant roll on the viscosity of the sample showed that the variation of cucumber fruit extract concentrations produce different viscosities as shown in Table 3.

The viscosity is highest on the formulation 3 at $187.123 \mathrm{cps}$ and the lowest viscosity formulation 1 at $80.211 \mathrm{cps}$. The

Table 7. Evaluation Organoleptic Accelerated Stability Test

\begin{tabular}{|c|c|c|c|c|c|c|}
\hline \multirow{2}{*}{ Formulation } & \multirow{2}{*}{ Temperature } & \multicolumn{5}{|c|}{ Organoleptic (color, smell) at week- } \\
\hline & & 1 & 2 & 3 & 4 & 5 \\
\hline \multirow[t]{3}{*}{ Blanko } & $\pm 28-30^{\circ} \mathrm{C}$ & Clear rosae & Clear rosae & Clear rosae & Clear rosae & Clear rosae \\
\hline & $40^{\circ} \mathrm{C}$ & Clear rosae & Clear rosae & Clear rosae & Clear rosae & Clear rosae \\
\hline & $\pm 28-30^{\circ} \mathrm{C}$ & $\begin{array}{c}\text { Clear yellow, } \\
\text { rosae }\end{array}$ & $\begin{array}{l}\text { Clear yellow, } \\
\text { rosae }\end{array}$ & $\begin{array}{c}\text { Clear yellow, } \\
\text { rosae }\end{array}$ & $\begin{array}{l}\text { Clear yellow, } \\
\text { rosae }\end{array}$ & $\begin{array}{c}\text { Clear yellow, } \\
\text { rosae }\end{array}$ \\
\hline \multirow{2}{*}{1} & $40^{\circ} \mathrm{C}$ & $\begin{array}{l}\text { Clear yellow, } \\
\text { rosae }\end{array}$ & $\begin{array}{l}\text { Clear yellow, } \\
\text { rosae }\end{array}$ & $\begin{array}{l}\text { Clear yellow, } \\
\text { rosae }\end{array}$ & $\begin{array}{l}\text { Clear yellow, } \\
\text { rosae }\end{array}$ & $\begin{array}{c}\text { Clear yellow, } \\
\text { rosae }\end{array}$ \\
\hline & $\pm 28-30^{\circ} \mathrm{C}$ & $\begin{array}{l}\text { Light yellow, } \\
\text { rosae }\end{array}$ & $\begin{array}{l}\text { Light yellow, } \\
\text { rosae }\end{array}$ & $\begin{array}{l}\text { Light yellow, } \\
\text { rosae }\end{array}$ & $\begin{array}{l}\text { Light yellow, } \\
\text { rosae }\end{array}$ & $\begin{array}{l}\text { Light yellow, } \\
\text { rosae }\end{array}$ \\
\hline 2 & $40^{\circ} \mathrm{C}$ & $\begin{array}{l}\text { Light yellow, } \\
\text { rosae }\end{array}$ & $\begin{array}{l}\text { Light yellow, } \\
\text { rosae }\end{array}$ & $\begin{array}{l}\text { Light yellow, } \\
\text { rosae }\end{array}$ & $\begin{array}{l}\text { Light yellow, } \\
\text { rosae }\end{array}$ & $\begin{array}{l}\text { Light yellow, } \\
\text { rosae }\end{array}$ \\
\hline \multirow{2}{*}{3} & $\pm 28-30^{\circ} \mathrm{C}$ & Yellow, rosae & Yellow, rosae & Yellow, rosae & Yellow, rosae & Yellow, rosae \\
\hline & $40^{\circ} \mathrm{C}$ & Yellow, rosae & Yellow, rosae & Yellow, rosae & Yellow, rosae & Yellow, rosae \\
\hline
\end{tabular}


Table 8. Evaluation Homogeneity Accelerated Stability Test

\begin{tabular}{ccccccc}
\hline \multirow{2}{*}{ Formulation } & Temperature & \multicolumn{5}{c}{ Homogeneity at week- } \\
\cline { 2 - 7 } & & $\mathbf{1}$ & $\mathbf{2}$ & $\mathbf{3}$ & $\mathbf{4}$ & $\mathbf{5}$ \\
\hline \multirow{2}{*}{ Blanko } & $\pm 28-30^{\circ} \mathrm{C}$ & $\mathrm{H}$ & $\mathrm{H}$ & $\mathrm{H}$ & $\mathrm{H}$ & $\mathrm{H}$ \\
& $40^{\circ} \mathrm{C}$ & $\mathrm{H}$ & $\mathrm{H}$ & $\mathrm{H}$ & $\mathrm{H}$ & $\mathrm{H}$ \\
\multirow{2}{*}{1} & $\pm 28-30^{\circ} \mathrm{C}$ & $\mathrm{H}$ & $\mathrm{H}$ & $\mathrm{H}$ & $\mathrm{H}$ & $\mathrm{H}$ \\
& $40^{\circ} \mathrm{C}$ & $\mathrm{H}$ & $\mathrm{H}$ & $\mathrm{H}$ & $\mathrm{H}$ & $\mathrm{H}$ \\
2 & $\pm 28-30^{\circ} \mathrm{C}$ & $\mathrm{H}$ & $\mathrm{H}$ & $\mathrm{H}$ & $\mathrm{H}$ & $\mathrm{H}$ \\
& $40^{\circ} \mathrm{C}$ & $\mathrm{H}$ & $\mathrm{H}$ & $\mathrm{H}$ & $\mathrm{H}$ & $\mathrm{H}$ \\
3 & $\pm 28-30^{\circ} \mathrm{C}$ & $\mathrm{H}$ & $\mathrm{H}$ & $\mathrm{H}$ & $\mathrm{H}$ & $\mathrm{H}$ \\
& $40^{\circ} \mathrm{C}$ & $\mathrm{NH}$ & $\mathrm{NH}$ & $\mathrm{NH}$ & $\mathrm{NH}$ & $\mathrm{NH}$ \\
\hline
\end{tabular}

Note: $\mathrm{H}=$ Homogeneous, $\mathrm{NH}=$ No Homogeneous

viscosity difference is probably influenced by the concentration difference cucumber extract added. Evaluation of flow properties of roll on deodorant preparations have good flow properties because they are within the standard range of the viscometer flow time of 20 to 400 second.

The result of irritation test for 10 panelists (5 female and 5 male panelists) showed that there was no statement of complaint skin irritation after using deodorant roll on are applied directly to the armpit. Therefore, roll on deodorant preparation is safe for use in the armpit. The result shown in Table 4.

Hedonic test evaluation results indicate that deodorant roll on formulation 3 has an average value of 3.6 is the highest are in the range of 3-4, it is because the scent of deodorant roll on preferred by the panelists for aroma possibility oleum rosae and cucumbers produce aromas tasty. The
Result shown in Table 5.

Deodorant roll on samples that have been made at the optimum condition to test the antibacterial activity against Staphylococcus epidermidis using Mueller Hinton medium which had been sterilized. Antibacterial inhibition against Staphylococcus epidermidiscan be seen in the figure 1 and Table 6.

Based on the fig. 1 and Table 6 shows that the formulation 3 has a large diameter of the inhibitory zone with cucumber extract concentration of $20 \%$. This is probably due to saponins in the cucumber so that the higher the concentration of extracts of cucumber, the higher the inhibitory power against Staphylococcus epidermidis bacteria.

Accelerated stability test were conducted for 35 days with temperature $28^{\circ} \mathrm{C}$ and $40^{\circ} \mathrm{C}$, and the evaluation is done

Table 9. Evaluation $\mathrm{pH}$ Accelerated Stability Test

\begin{tabular}{ccccccc}
\hline \multirow{2}{*}{ Formulation } & Temperature & \multicolumn{5}{c}{ pH at week- } \\
\cline { 2 - 6 } & & $\mathbf{1}$ & $\mathbf{2}$ & $\mathbf{3}$ & $\mathbf{4}$ & $\mathbf{5}$ \\
\hline \multirow{2}{*}{ Blanko } & $\pm 28-30^{\circ} \mathrm{C}$ & 5,49 & 5,49 & 5,48 & 5,48 & 5,47 \\
& $40^{\circ} \mathrm{C}$ & 5,46 & 5,44 & 5,43 & 5,42 & 5,40 \\
\multirow{2}{*}{1} & $\pm 28-30^{\circ} \mathrm{C}$ & 5,50 & 5,49 & 5,47 & 5,46 & 5,44 \\
& $40^{\circ} \mathrm{C}$ & 5,49 & 5,49 & 5,48 & 5,47 & 5,47 \\
2 & $\pm 28-30^{\circ} \mathrm{C}$ & 5,55 & 5,55 & 5,54 & 5,53 & 5,53 \\
& $40^{\circ} \mathrm{C}$ & 5,55 & 5,54 & 5,54 & 5,53 & 5,51 \\
& $\pm 28-30^{\circ} \mathrm{C}$ & 5,59 & 5,58 & 5,58 & 5,57 & 5,56 \\
& $40^{\circ} \mathrm{C}$ & 5,57 & 5,56 & 5,55 & 5,53 & 5,51 \\
\hline
\end{tabular}


Table 10. Evaluation Viscosity Accelerated Stability Test

\begin{tabular}{ccccccc}
\hline \multirow{2}{*}{ Formulation } & Temperature & \multicolumn{5}{c}{ Viscosity (centipoise) at week- } \\
\cline { 3 - 7 } & & $\mathbf{1}$ & $\mathbf{2}$ & $\mathbf{3}$ & $\mathbf{4}$ & $\mathbf{5}$ \\
\hline \multirow{2}{*}{ Blanko } & $\pm 28-30^{\circ} \mathrm{C}$ & 180,009 & 180,004 & 179,574 & 179,574 & 179,014 \\
& $40^{\circ} \mathrm{C}$ & 170,014 & 179,014 & 178,684 & 178,684 & 177,688 \\
& $\pm 28-30^{\circ} \mathrm{C}$ & 80,211 & 80,211 & 79,695 & 79,695 & 79,710 \\
\multirow{2}{*}{1} & $40^{\circ} \mathrm{C}$ & 79,710 & 79,740 & 79,238 & 79,268 & 78,765 \\
& $\pm 28-30^{\circ} \mathrm{C}$ & 172,206 & 171,706 & 171,706 & 171,143 & 170,611 \\
2 & $40^{\circ} \mathrm{C}$ & 171,143 & 170,611 & 170,240 & 169,708 & 169,708 \\
& $\pm 28-30^{\circ} \mathrm{C}$ & 187,619 & 187,619 & 187,193 & 187,193 & 187,128 \\
3 & $40^{\circ} \mathrm{C}$ & 187,228 & 187,264 & 186,802 & 186,837 & 186,375 \\
\hline
\end{tabular}

every single week (1 cycle). Observations organoleptic deodorant roll on sample showed that formulation blanko, 1, 2, and 3 formulation is stable at room temperature $28^{\circ} \mathrm{C}$ and high temperature $40^{\circ} \mathrm{C}$. The smell of perfume and color preparation does not change from week 1 to 5 . The result shown in Table 7 below.

The homogeneity stability evaluation has shown that all samples showed high homogeneity at room temperature up to $\pm 28-30^{\circ} \mathrm{C}$ from the week 1 to week 5 , while there is a low degree of homogeneity at high temperatures $40^{\circ} \mathrm{C}$ to produce a precipitate since the first week. This results indicates that the sample deodorant roll on unstable at high temperatures as shown in Table 8 .

The results of the measurement of $\mathrm{pH}$ stability in sample showed that the $\mathrm{pH}$ in the formulation blanko, 1, 2, and 3 at room temperature $\pm 28-30^{\circ} \mathrm{C}$ and high temperature $40^{\circ} \mathrm{C}$ decreased $\mathrm{pH}$ insignificat. $\mathrm{pH}$ measurement on the sample were observed for 35 days ranged from 5.40 to 5.59 still within the normal $\mathrm{pH}$ range of underarm skin which is $\mathrm{pH}$ 4-7. It means sample deodorant roll on does not irritate the skin when applied to the skin as shown in Table 9.

Evaluation of viscosity stability preparation deodorant roll on the formulation negative control, 1, 2, and 3 formulation at room temperature $28^{\circ} \mathrm{C}$ and high temperature $40^{\circ} \mathrm{C}$ from week 1 to week 5 decreased viscosity every week so that sample deodorant roll on to be a litte bit watery. It happen because thickening agent HPCM incompatible with the phenol derivative contained in extract cucumber so that the viscosity decrease during the period storage. This decreases the viscosity according to the Arrhenius law said that all preparations stored for certain period of time will reduction viscosity [9]. The results of an accelerated stability viscosity are shown in Table 10.

\section{Conclusions}

Based on the dosage formulation research deodorant roll on extracts of cucumber (Cucumis sativus L.) can be concluded that extract the cucumber can be made deodorant roll on, and it can be inhibit the growth of Staphylococcus epidermidis which is the cause of body odor. Deodorant from cucumber extract relatively safer to use because of natural materials. The best results of this formulation is formula 2 with cucumber extract concentration of $10 \%$ that have the most qualified physical quality, and also provided minimum inhibitory zone of $16 \mathrm{~mm}$. Further research is needed to examine the effect of extracts of cucumber in the form of deodorant roll on against underarm odor-causing bacteria such as Staphylococcus aureus.

\section{Acknowlegment}

I acknowledge the research personnel Department of Pharmacy, University of 
Tulang Bawang Lampung and Botany Laboratoy University of Lampung.

\section{Refferences}

[1] Havlicek, J and Lenochova, P. 2006. Environmental Effects on Human Body Odour. Charles University, Department of Anthropology. pp. 199- 200

[2] Bhutta MF. 2007. Sex and the nose: human pheromonal responses. $R$ Soc Med J .; 100 (6): 268-274.

[3] Mitsui, T., 1998. New Cosmetic Science. Edisi I, Amsterdam, 158- 159.

[4] Kerr, R.G., and Chen, Z. 1995. In Vivo and In Vitro Biosynthesis of Saponins in Sea Cucumbers. Journal of Natural Products. 58, 2, pp 172-176.

[5] Ni Foong, F.H., Mohammad, A., Ichwan, A.J.S. 2015. Biological Properties of Cucumber (Cucumis sativa L.) Extracts. Malaysian Journal of Analitycal Sciences. 19, 6, pp. 12181222.

[6] Tang J., Meng X., Liu H., Zhao J., Zhou L., and Yang F. 2010. Antimicrobial activity of Sphingolipids isolated from $\mathrm{t} \mathrm{h}$ e stems of Cucumber (Cucumis sativus L.). Molecules, 15: 9288- 9297.

[7] Yusvaneli, 2008. "Uji Daya Antibakteri Sari Buah Mentimun (Cucumis sativus L.) Terhadap Staphylococcus epidermidis", Skripsi, Jurusan

Farmasi Fakultas Matematika dan Ilmu Pengetahuan Alam, Universitas

Tulang Bawang, Bandar Lampung, 4-22.

[8] Alzomor, A.K., Moharram, A.S., Al Absi N.M. 2014. Formulation and Evaluation of Potash Alum As Deodorant Lotion And After Shaving Astringent As Cream And Gel. International Current Pharmaceutical Journal. 3, 2, pp.228-233.

[9] Martin, A., J. Swarbrick, dan A. Cammarata 2008. Farmasi Fisika Dasar- Dasar Kimia Fisik Dalam
Ilmu Farmasetik Edisi 3. UI Press. Jakarta. 